\title{
PHARMACOLOGY AND TOXICOLOGY
}

\section{Effect of New Antiviral Agent Camphecin on Behavior of Mice A. V. Babina ${ }^{1}$, V. A. Lavrinenko ${ }^{1}$, O. I. Yarovaya ${ }^{1,2}$, and N. F. Salakhutdinov ${ }^{1,2}$}

Translated from Byulleten'Eksperimental'noi Biologii i Meditsiny, Vol. 162, No. 9, pp. 329-332, September, 2016 Original article submitted July 29, 2015

\begin{abstract}
We studied the effect of camphecin (1,7,7-trimethylbicyclo[2.2.1]heptan-2-ylidene-aminoethanol) on mouse behavior in the open-field test. Camphecin possesses antiviral activity and inhibits viral replication, but its influence on the nervous system is poorly studied. Single camphecin injection produced no significant changes in behavioral patterns. Chronic camphecin administration ( 5 times over 2 weeks) to mice of different strains had no significant influence on open field behavior (motor, exploratory activity, anxiety, emotional state and vegetative functions). The findings are discussed in the context of neutral influence of camphecin on animal behavior.
\end{abstract}

Key Words: camphecin; anxiety; locomotor activity

Development of new drugs for the therapy and prevention of viral infections remains a priority problem of modern pharmacology and medical chemistry. Antiviral agents for the therapy of influenza are a very limited group of drugs, and for most these drugs, resistance has been demonstrated. Creation of antiviral drugs is in the short-term outlook of medical science development in the field of treatment and prevention of viral infections [1].

Camphecin (1,7,7-trimethylbicyclo [2.2.1]heptan2-ylidene-aminoethanol) exhibits pronounced antiviral activity (inhibits viral hemagglutinin) and possesses low toxicity [7]. Chemotherapeutic index of this compound is more than 100-fold higher than that of the reference compounds [2]. The advantage of this drug is its activity against rimantadine-resistant strain of influenza virus A/California/07/09 (H1N1) pdm09, indicating a promising outlook for its application against epidemiologically relevant viruses, the vast majority of which is resistant to rimantadine.

${ }^{1}$ Novosibirsk National Research State University; ${ }^{2}$ N. N. Vorozhtsov Novosibirsk Institute of Organic Chemistry of Siberian Division of Russian Academy of Sciences, Russia. Address for correspondence: igor@academ.org. V. A. Lavrinenko
However, the effect of camphecin on integrative activity of the brain underlying behavior has not been studied [6].

The aim of this study was to investigate the effect of camphecin on behavior of mice of different strains in the open-field (OF) test.

\section{MATERIALS AND METHODS}

Experiments were carried out on 3-4-month-old male and female mice $(n=450)$ of different strains (CD1, $\mathrm{AKR}, \mathrm{C} 57 \mathrm{Bl} / 6, \mathrm{C} 3 \mathrm{H}, \mathrm{DBA}$, and $\mathrm{CBA}$ ) weighing $28 \pm 0.5$ g. Animals were kept in cages $40 \times 25 \times 15$ $\mathrm{cm}, 10$ animals per group, under standard conditions $\left(22 \pm 2^{\circ} \mathrm{C}\right.$, relative humidity $65 \%$, natural lighting) with free access to water and food.

Two experimental series were designed with acute (single; $n=130)$ and chronic (5 injections within 2 weeks; $n=275$ ) camphecin administration. In both series, the mice were divided into two groups: control group received saline and experimental group received camphecin.

Camphecin (synthesized at the N. N. Vorozhtsov Novosibirsk Institute of Organic Chemistry) was ad- 
ministered intraperitoneally in a dose of $100 \mathrm{mg} / \mathrm{kg}$ body weight (in $0.1 \mathrm{ml}$ saline per $10 \mathrm{~g}$ body weight). After injection, the animals were kept in transporting cages for 10 min before being placed in OF.

Testing was conducted in an apparatus with a square illuminated arena divided into 25 equal 100$\mathrm{cm}^{2}$ squares surrounded with $25-\mathrm{cm}$ walls. Each animal was placed onto the arena near the wall, and its movement was recorded for 3 min using digital video camera positioned above the arena and connected to a TV. The video was analyzed frame by frame according to the accepted protocol [4]. Motor (locomotion along the periphery and in the central area of the arena) and exploratory (rearings) activity of rodents were assessed. Freezing and grooming time reflected animal anxiety and the number of fecal boluses showed the level of autonomic activity.

The data were statistically processed using Statistica 6.0. Significance of differences between the groups was assessed by Student's $t$ test for paired comparisons. For independent samples, significance of differences was estimated using one-way and twoway ANOVA, genotype and camphecin administration were taken as factors. The differences were significant at $p<0.05$.

\section{RESULTS}

The psychophysiological mechanism of behavior has a complex neurotransmitter nature. Moreover, readiness

TABLE 1. Effect of Single Camphecin Administration on Behavioral Patterns in Mice $(M \pm S E M)$

\begin{tabular}{|c|c|c|c|c|c|c|c|}
\hline \multirow[b]{2}{*}{ Behavior pattern } & \multicolumn{2}{|c|}{ OF test } & \multicolumn{5}{|c|}{ ANOVA } \\
\hline & $\begin{array}{l}\text { control } \\
(n=64)\end{array}$ & $\begin{array}{l}\text { camphecin } \\
\quad(n=66)\end{array}$ & SS & df & MS & $F$ test & $\begin{array}{l}p \text { in compa } \\
\text { rison with } \\
\text { the control }\end{array}$ \\
\hline $\begin{array}{l}\text { Locomotion in the periphery } \\
\text { of the arena, sec } \\
\text { Locomotion in the center } \\
\text { of the arena, sec }\end{array}$ & $118.18 \pm 3.95$ & $112.47 \pm 4.74$ & 1058 & 1 & 1058 & 0.850 & 0.36 \\
\hline Rearings, sec & $65.86 \pm 6.76$ & $65.85 \pm 7.05$ & 173.29 & 1 & 173.29 & 1.073 & 0.302 \\
\hline $\begin{array}{l}\text { Autonomic activity, number } \\
\text { of fecal boluses }\end{array}$ & $2.25 \pm 0.22$ & $1.62 \pm 0.21$ & 12.8466 & 1 & 12.8466 & 4.3326 & 0.039 \\
\hline Grooming, sec & $50.21 \pm 6.50$ & $49.68 \pm 6.81$ & 9.1 & 1 & 9.1 & 0.0032 & 0.96 \\
\hline $\begin{array}{l}\text { Freezing, sec } \\
\text { Error }\end{array}$ & $45.12 \pm 6.86$ & $64.98 \pm 7.05$ & 12815.7 & $\begin{array}{c}1 \\
128\end{array}$ & 12815.7 & 4.0681 & 0.046 \\
\hline
\end{tabular}

TABLE 2. Effect of Chronic Camphecin Administration on Behavioral Patterns in Mice $(M \pm S E M)$

\begin{tabular}{|c|c|c|c|c|c|c|c|}
\hline \multirow[b]{2}{*}{ Behavior pattern } & \multicolumn{2}{|c|}{ OF } & \multicolumn{5}{|c|}{ ANOVA } \\
\hline & $\begin{array}{l}\text { control } \\
(n=64)\end{array}$ & $\begin{array}{l}\text { Camphecin } \\
\quad(n=66)\end{array}$ & SS & df & MS & $F$ test & $\begin{array}{l}p \text { in compa } \\
\text { rison with } \\
\text { the control }\end{array}$ \\
\hline $\begin{array}{l}\text { Locomotion in the periphery } \\
\text { of the arena, sec } \\
\text { Locomotion in the center } \\
\text { of the arena, sec }\end{array}$ & $146.59 \pm 5.28$ & $151.95 \pm 5.00$ & 1976 & 1 & 1976 & 0.544 & 0.46 \\
\hline Rearings, sec & $64.43 \pm 5.66$ & $72.11 \pm 6.13$ & 4062 & 1 & 4062 & 0.8460 & 0.36 \\
\hline $\begin{array}{l}\text { Autonomic activity, number } \\
\text { of fecal boluses }\end{array}$ & $8.55 \pm 2.02$ & $7.80 \pm 2.03$ & 38.4 & 1 & 38.41 & 0.06862 & 0.79 \\
\hline Grooming, sec & $72.45 \pm 6.36$ & $61.84 \pm 6.12$ & 7679 & 1 & 7679 & 1.4453 & 0.23 \\
\hline $\begin{array}{l}\text { Freezing, sec } \\
\text { Error }\end{array}$ & $84.69 \pm 6.57$ & $81.46 \pm 6.86$ & 717 & $\begin{array}{c}1 \\
273\end{array}$ & 717 & 0.1155 & 0.73 \\
\hline
\end{tabular}


of an individual to this or that behavioral program can be determined by genetic factors. In this study, mice of different genetic strains were used, but no significant effect of the genotype on behavior of mice was revealed. Therefore, data from different genotypes were combined and results of one-way analysis of variance are shown.

Acute (single) administration of camphecin had no effect on locomotor activity in the center and at the periphery of OF, as well as on the number of rearings (Table 1). The animals demonstrating high physical activity and intensive rearing in the test were considered low emotional with high exploratory motivation. Exploration of central squares of OF by animals attests to low fear. However, experimental mice receiving single camphecin injection showed significantly increased freezing time in OF in comparison with the controls (Table 1), which was interpreted as increased anxiety. Grooming time and autonomic activity (number of fecal boluses) also indicated increased anxiety in OF [3]. No changes in grooming time were observed in mice receiving single camphecin injection in comparison with the control group. At the same time, autonomic activity was reduced after camphecin administration (Table 1 ), which can indirectly attest to changes in the tone of the parasympathetic regulation centers [5]. Thus, no sufficient changes in animal behavior were revealed after single camphecin administration.

Chronic camphecin administration to mice did not significantly affect their behavior. Motor activity at the periphery and in the center of OF, duration of rearings, grooming and freezing, as well as activity of the autonomic nervous system did not differ from the corresponding parameters in the control group (Table 2).
One-way ANOVA confirmed the revealed patterns in case of single and chronic administration of the new antiviral agent camphecin.

Obtained data demonstrate absence of inhibitory effect of camphecin on the integrative activity of the brain, which controls behavior.

The study was supported by Russian Science Foundation (grant No. 15-13-17).

\section{REFERENCES}

1. Eropkin MYu, Zarubaev VV. Current status of new antiviral drugs against influenza and SARS. Farmatsev. Byull. 2012(1):68-75. Russian.

2. Jarovaja OI, Sokolova AS, Tretjak TS, Zarubaev VV, Kiselev OI, Salakhutdinov NF. Patent RF No. 2530554. Using 1,7,7-trimethylbicyclo[2,2,1]heptan-2-ylidene-aminoethanol as influenza virus reproduction inhibitor. Bull. No. 28. Published October 10, 2014.

3. Kalueff AV, Aldridge JW, LaPorte JL, Murphy DL, Tuohimaa P. Analyzing grooming microstructure in neurobehavioral experiments. Nat. Protoc. 2007;2(10):2538-2544.

4. Kulikov AV, Tikhonova MA, Kulikov VA. Automated measurement of spatial preference in the open field test with transmitted lighting. J. Neurosci. Methods. 2008;170(2):345-351.

5. Prut L, Belzung C. The open field as a paradigm to measure the effects of drugs on anxiety-like behaviors: a review. Eur. J. Pharmacol. 2003;463(1-3):3-33.

6. Young JW, Geyer MA. Using behavioral patterns across species in mood disorders research. Mood and anxiety related phenotypes in mice: characterization using behavioral test; Vol. II. New York, 2009. Vol. II. P. 21-41. doi: 10.1007/9781-61779-313-4 2.

7. Zarubaev VV, Garshinina AV, Tretiak TS, Fedorova VA, Shtro AA, Sokolova AS, Yarovaya OI, Salakhutdinov NF. Broad range of inhibiting action of novel camphor-based compound with anti-hemagglutinin activity against influenza viruses in vitro and in vivo. Antiviral Res. 2015;120:126-133. 